\title{
ON (NOT) BELIEVING THAT GOD HAS ANSWERED A PRAYER
}

\author{
Brian Embry
}

\begin{abstract}
Scott Davison has raised an epistemic challenge to the doctrine of petitionary prayer. Roughly, the challenge is that we cannot know or have reason to believe that a prayer has been answered. Davison argues that the epistemic challenge undermines all the extant defenses of petitionary prayer. I argue that it does not.
\end{abstract}

Judaism, Christianity, and Islam all advocate the doctrine of petitionary prayer: we should use prayer to ask God for things, and God will sometimes answer those prayers. In his 2011 paper and again in his 2017 book, Scott Davison raises an epistemic challenge to the doctrine of petitionary prayer. In the 2011 paper, Davison argues that we can never have any reason to believe of a prayer that God has answered it. This fact allegedly "undermines all the extant defenses of the practice" of petitionary prayer. ${ }^{1}$ In his more recent book, Davison argues at length for the less ambitious claim that maybe we don't know of any prayer that God has answered that prayer. ${ }^{2}$ As weak as the latter claim is, Davison still thinks that it "appear[s] to undermine some of the most popular defenses of petitionary prayer." 3

There are two ways to respond to Davison's epistemic challenge. First, the defender of petitionary prayer might argue that we sometimes do have reason to believe (or we sometimes do know) that God has answered a particular prayer. ${ }^{4}$ This strategy implicitly grants or suggests that if we do not have reason to believe that God has answered a prayer, then the extant defenses of petitionary prayer are indeed undermined by Davison's epistemic challenge. If the arguments developed for this strategy are found to be problematic, then the doctrine of petitionary prayer will be

${ }^{1}$ Davison, "Petitionary Prayer," 298. For an overview of the literature, see Smith, "Philosophical Reflections." In addition to the works cited below, helpful entries to the debate include Basinger, "Petitionary Prayer" and "God Does Not Respond"; Franks, "Why a Believer Could Believe"; Hoffman, "On Petitionary Prayer"; Smith and Yip, "Partnership with God"; Stump, "Hoffman on Petitionary Prayer"; and Veber, "Why Even a Believer Should Not Believe."

${ }^{2}$ Davison, Petitionary Prayer, chapter 4.

${ }^{3}$ Davison, Petitionary Prayer, 18.

${ }^{4}$ Choi, "Is Petitionary Prayer Superfluous?" 
to that extent impugned. The defender of petitionary prayer would be in a more stable position if it were shown that the doctrine of petitionary prayer is in no way impugned by the fact that we do not have reasons to believe (or that we do not know) that God has answered a particular prayer. This paper develops this second response to Davison's epistemic challenge. I will focus exclusively on Davison's 2011 argument. This is because Davison's 2011 claim that we never have any reason to believe that a prayer has been answered is obviously much stronger than the 2017 claim that maybe we do not know that a prayer has been answered. If I can show that the 2011 claim does not undermine the extant defenses of petitionary prayer, then it will follow that the 2017 claim does not either. The paper proceeds as follows. First I explain why Davison holds in the 2011 paper that we never have any reason to believe that a prayer has been answered. Next, I explain how this fact allegedly undermines the extant defenses of petitionary prayer. Finally, I show how the defender of petitionary prayer may resist Davison's argument.

Davison makes an ingenious contribution to the literature on petitioner prayer when he takes a step back and asks a question the answer to which is typically taken for granted: under what conditions is it correct to say that God has answered a prayer? It is widely assumed that God does not answer prayers for bad things, so one condition on being an answered prayer is that the prayer must have been for something good. It is also widely assumed that for the prayer to count as answered, it must be the case that God brings about the thing being prayed for. These two conditions, however, might seem insufficient for answered prayer, since God might bring about what is being prayed for independently of the prayer. It is naturally (and commonly) assumed that in addition to the object of a prayer being good and being brought about by God, God's bringing about the object of the prayer must depend counterfactually on the prayer. This additional condition completes the counterfactual dependence account of answered prayer.

\section{The counterfactual dependence account of prayer}

S's prayer for $\mathrm{x}$ is answered if and only if

(i) $\mathrm{x}$ is good,

(ii) God brings about $x$, and

(iii) God would not have brought about $\mathrm{x}$ if $\mathrm{S}$ had not prayed for $\mathrm{x} .{ }^{5}$

The counterfactual dependence account is subject to pre-emption problems similar to those found in the literature on counterfactual theories of causation. Suppose that you and your aunt both pray for your mother's

${ }^{5}$ Davison's version of the counterfactual dependence account omits condition (ii). Doing so opens the counterfactual dependence account to even more problems (Davison, "Petitionary Prayer," 288), which are easily avoided by including condition (ii). 
recovery from illness, your mother's recovery is a good thing, and God brings about your mother's recovery. It seems possible for the following two conditions to obtain: (i) God answers your prayer for your mother's recovery, and (ii) even if you had not prayed for your mother's recovery, God would have brought about your mother's recovery in response to your aunt's prayer. But according to the counterfactual dependence account, these two conditions cannot both obtain, since if the second condition obtains, then God's bringing about your mother's recovery does not depend counterfactually on your prayer; hence, God did not answer your prayer. But intuitively God can answer your prayer and also answer your aunt's prayer in such a way that God would have answered your aunt's prayer even if you had not prayed (and vice versa). ${ }^{6}$

To address the pre-emption problem with the counterfactual dependence account, Davison recommends replacing condition (iii) of the counterfactual dependence account with the condition characteristic of his own reasons account of answered prayer:

\section{The reasons account of answered prayer:}

S's prayer for $\mathrm{x}$ is answered if and only if

(i) $x$ is good,

(ii) God brings about $x$, and

(iii) God brings about $x$ at least in part because $S$ prayed for $x{ }^{7}$

${ }^{6}$ Here I am thinking of prayers as utterances. The same point can be made, mutatis $m u$ tandis, thinking of prayers as the contents of utterances.

${ }^{7}$ Davison, "Petitionary Prayer," 288. In Petitionary Prayer, chapter 4, Davison finds fault with the reasons account on the grounds that it "does not explain the sense in which a petitionary prayer must make some kind of difference in order to count as having been answered by God" (34). Davison's reason for this claim is that on the reasons account, the fact that someone prayed for something might constitute only a very slight reason for God to do something, in which case the prayer does not really make a difference. To address this problem, Davison replaces the reasons account with the contrastive reasons account:

CRA: S's petitionary prayer (token) for an object $\mathrm{E}$ is answered by God if and only if God's desire to bring about $E$ just because $S$ requested it plays an essential role in a true contrastive explanation of God's bringing about $\mathrm{E}$ rather than not.

The difference between the reasons account and the contrastive reasons account is irrelevant with respect to Davison's epistemic challenge, and I will focus on the reasons account for simplicity. But it is worth noting that CRA faces a serious difficulty. Suppose that God has no independent reason to provide my son a jackknife, but I organize a prayer meeting in which 12 million people pray for my son to receive a jackknife. It seems possible for God to answer our prayers, although each prayer (token) constitutes only a very slight reason for God to provide my son a jackknife. Davison seems to think that in such a case, no prayer token plays an essential role in a true contrastive explanation of God's providing my son a jackknife. If not, it follows that God did not answer anyone's prayer, although God did provide my son a jackknife because of all those prayers. But if any of the 12 million prayer tokens does play an essential role in a true contrastive explanation of God's providing my son a jackknife, then a very slight reason can play such a role, and CRA faces the same "problem" that the reasons account faces. 
The "because" in the third condition signifies a motivating reason: to say that God brings about $x$ at least in part because $S$ prayed for $x$ is to say that $S$ 's praying for $x$ constitutes a motivating reason (perhaps one among many) for God to bring about $x$. Because persons can act for a multitude of reasons, the reasons account does not entail counterfactual dependence of the prayer's being answered on the prayer itself, and it is therefore not subject to the pre-emption problem. If you and your aunt both pray for your mother's recovery from illness, God can bring about your mother's recovery while taking both prayers into account. As long as God brings about your mother's recovery at least in part because you prayed for it, and at least in part because your aunt prayed for it, it follows from the reasons account that God answered both prayers. ${ }^{8}$

The reasons account of answered prayer seems correct, but Davison argues that it leads to intractable problems for the doctrine of petitionary prayer, one of which he dubs the "reasons-skeptical problem." The problem is that we ordinarily have no insight into God's reasons for doing things. If God brings about your mother's recovery, we cannot know anything about why God does that. A fortiori, we cannot know that God brings about your mother's recovery because someone prayed for it. Consequently, we cannot know that God's bringing about your mother's recovery constitutes an answered prayer rather than a coincidence. Not only can we not ordinarily know that God has answered a prayer, but it seems we cannot even have any reason to believe that God has answered a prayer, since we have no epistemic access to God's reasons for acting in the world. Davison claims that the reasons-skeptical problem undermines the extant defenses of petitionary prayer. In order to evaluate that claim, we must consider briefly why petitionary prayer is supposed to need defending in the first place.

Philosophers and theologians have alleged that the doctrine of petitionary prayer conflicts with the classical conception of God as perfectly good. The argument is roughly as follows. Suppose I ask God for something. If what I ask for is good all things considered, then God, being perfectly good, will provide what I ask for, whether or not I ask for it. If what I ask for is bad, then God, being perfectly good, will not provide what I ask for, whether or not I ask for it. In either case, God does not answer my prayer. The (alleged) upshot is that the major theistic religions are incoherent insofar as they advocate petitionary prayer and also hold that God is perfectly good; meanwhile, millions of religious believers engage in and often center their lives around a pointless practice. ${ }^{9}$

${ }^{8}$ In Petitionary Prayer, Davison distinguishes between answering a prayer and responding to a prayer. Answering a prayer requires providing the object of the prayer. One can respond to a prayer by merely saying "no" (10).

${ }^{9}$ Several non-equivalent versions of this argument are often conflated in the literature: some conclude that God does not answer petitionary prayers; some conclude that even if God does answer petitionary prayers, such prayers are pointless; and some simply pose the question, why would God institute the practice of petitionary prayer? Because I am focusing 
A common response to the problem of divine goodness is to say that God achieves certain "outweighing goods" by responding to petitionary prayer. I will not discuss all the goods alleged to justify the doctrine of petitionary prayer, but I will focus on those goods that I take to be plausible justifications for making some goods contingent on prayer and that can withstand Davison's critique. My purpose in focusing on these goods is not to endorse them as providing the best defense of petitionary prayer, but rather to show how such defenses can generally withstand Davison's attack. My defense can be adapted to many other justifications for making goods contingent on prayer, but not to all of them. ${ }^{10}$

The practice of petitionary prayer is tied to the assumption that God is a person who responds to our needs when asked. Petitionary prayer therefore helps us to get into and maintain a personal relationship with God. Just like any relationship, one's relationship with God would be impoverished if it did not include some sort of responsive element, where one party responds to the other. In our relationship with God this responsiveness comes by way of petitionary prayer. By making some goods dependent on petitionary prayer, God gives us an incentive to enter into personal interactions with God by way of petitionary prayer. Such an incentive might be especially useful for those who are inclined to argue that prayer is pointless if we are going to get what we need even if we do not pray. ${ }^{11}$

In the article that kick-started the literature on petitionary prayer, Eleonore Stump argues that making goods contingent on prayer is one way to safeguard against two dangers inherent in any relationship with a significant power imbalance. ${ }^{12}$ Where one person in the relationship is more powerful than the other, if the powerful person acts in the less powerful person's life without restraint, then the less powerful person is likely to feel overwhelmed by the more powerful person and to resent the more powerful person as meddlesome. However, if the more powerful person were to restrain herself by intervening only when asked, then the help would be welcome because requested. To use Stump's example, if a teacher calls uninvited on a struggling student to help the student arrange her schedule more efficiently and to ensure the student is spending enough time on course material, the student might feel like the teacher is intruding. But if the student approaches the teacher after class and asks for help, then it would be irrational for the student to resent the teacher for helping. Stump also argues that God's providing all goods automatically runs the risk of spoiling us, making us wilful and tyrannical. ${ }^{13}$ By making

on the responses to these arguments, I will not discuss the nuanced differences between them.

${ }^{10}$ Howard-Snyder and Howard-Snyder also respond to Davison's arguments, but their arguments are different from mine ("The Puzzle of Petitionary Prayer").

${ }^{11} \mathrm{~A}$ similar point is made in different terms by Murray and Meyers, "Ask and It Shall Be Given," 315, and by Choi, "Is Petitionary Prayer Superfluous?" 40.

${ }^{12}$ Stump, "Petitionary Prayer."

${ }^{13}$ Stump, "Petitionary Prayer," 89; Murray and Meyers, "Ask and It Shall be Given," 316. 
goods contingent on prayer, God helps us to recognize our dependence, which elicits an attitude of gratefulness. ${ }^{14}$ The practice of petitionary prayer therefore also guards against idolatry, since it forces us to recognize God as our provider. ${ }^{15}$

The foregoing benefits of petitionary prayer can be summarized by saying that petitionary prayer enriches one's relationship with God by achieving the following results:

1. Providing an incentive to enter into personal interactions with God

2. Guarding against divine meddling

3. Demonstrating our dependence on God for some goods, thereby

i. guarding us from spoilage, and

ii. guarding us from idolatry.

I will call these responses to the argument from goodness collectively "the relationship defenses."

Davison argues that all the standard responses to the argument from goodness, including the relationship defenses, are undermined by the reasons-skeptical problem. ${ }^{16}$ Take them in reverse order. If we do not have any reason to believe that God has answered a prayer, we have no special reason to think that a good was dependent on God in any special way. ${ }^{17}$ Answered prayer therefore provides no check against spoilage and idolatry, since it gives us no reason to think our goods come from God in any special way. Davison also argues that the reasons-skeptical problem undermines the claim that making some goods contingent on prayer guards against divine meddling. He writes:

If we don't know which goods God bestows upon us as a result of petitionary prayer (as opposed to those goods God bestows on us just because we need them, whether or not we ask), then we won't know whether or not God is "respecting our boundaries," so to speak. ${ }^{18}$

In other words, if we cannot know whether God has answered a prayer, then we cannot know that God is not in fact meddling in our lives. Davison does not discuss the first justification for making some goods dependent on petitionary prayer-providing an incentive to engage in personal interaction with God through petitionary prayer. However, it might seem that the reasons-skeptical problem also undermines this justification for petitionary prayer for the same reason it undermines the others. If we have no

\footnotetext{
${ }^{14} \mathrm{~A}$ similar line can be found in Aquinas, ST IIa-IIae, Q. 83, A. 2.

${ }^{15}$ Murray and Meyers, "Ask and It Shall Be Given," 313-314; Murray, "God Responds."

${ }^{16}$ Davison, "Petitionary Prayer." As mentioned above, Davison tempers this claim in Petitionary Prayer; in the end it is not clear how strongly he intends it to be taken.

${ }^{17}$ We might have independent reason to think that everything is dependent on God as conserver of the universe, but whatever sense of dependence is involved in divine conservation is independent of petitionary prayer and so not relevant here.
}

${ }^{18}$ Davison, "Petitionary Prayer," 296. 
reason to think that God answers our prayers, we have no reason to think God will answer our future prayers. Accordingly, we have no incentive to pray for things. Such are the reasons why Davison thinks the reasonsskeptical problem undermines the above responses to the argument from goodness.

Even if one agrees that we typically have no reason to believe that God has answered a prayer, the reasons-skeptical problem does not undermine the relationship defenses. This is because the relationship defenses do not require that we have reason to believe of individual prayers that God has answered or will answer those prayers. To see this, it is useful to distinguish between two claims:

(A) For some prayer p, God has answered p;

(B) God answers prayers for goods that are contingent on prayers.

The reasons-skeptical problem undermines our reasons to believe instances of (A), but not (B). ${ }^{19}$ Davison argues that God is justified in making (B) true only if we have a reason to believe instances of (A). But I disagree. In order to justify making (B) true, it is sufficient that we have a justified belief that (B) is true; belief that some instance of $(\mathrm{A})$ is true is not required. So if we have an independent reason to believe (B), then God is justified in making (B) true. To see this, consider the three relationship defenses in turn.

According to the first defense, God makes some goods dependent on petitionary prayer in order to incentivize our engaging in personal interaction with God. The personal interaction consists in our approaching God in prayer in order to confess our need and ask for help and, in some cases, God answering the prayer by providing what we ask. Knowing that God makes some goods contingent on prayer is sufficient to incentivize asking God for things. Consider the following analogy. Suppose you had a rich and influential, but distant and mysterious benefactor (think of Ms. Havisham as Pip understands her for most of Great Expectations). This benefactor writes you a letter that reads:

My Dear Philosopher:

I am rich beyond compare and very influential. Whenever you need something, do write to me and let me know. I will answer your request if the circumstances allow it (but you must remember to write!). Unfortunately, you will not hear from me again, but rest assured I care for you and will answer your requests whenever possible. I look forward to hearing from you.

I am, etc.

${ }^{19}$ In his later work, Davison demonstrates awareness of the distinction between $(\mathrm{A})$ and (B), but he does not consider its importance vis-à-vis his attack on extant defenses of petitionary prayer (Davison, Petitionary Prayer, 62 and 108). 
If you received such a letter and had independent reasons to think it was legitimate, then you would have good reason to believe that (a) your benefactor will answer some of your requests, but (b) only if you write to her. Believing these things provides incentive to write to your benefactor whenever you need something. You would have such an incentive because you know that your benefactor will answer at least some of your requests, even if you do not know which of your requests she will answer.

However, your benefactor will not unilaterally wield her influence on your behalf. This is because your benefactor does not want to be meddlesome and wants to leave you a significant level of autonomy. Accordingly, your benefactor will wield her influence on your behalf only when you ask her to. By making her influence contingent on your asking, your benefactor guards against being meddlesome and advancing unwanted solutions to your problems. According to the second defense, the case is the same with God. Davison suggests that God cannot guard against being meddlesome because you do not know when God is helping and when not. Here it is useful to draw a distinction. There are three easily confused benefits associated with lack of meddling:

(i) You have reason to believe that God is not meddling in your affairs;

(ii) You do not have reason to believe that God is meddling in your affairs;

(iii) God is not meddling in your affairs.

Even if we grant that the reasons-skeptical problem undermines benefit (i), benefits (ii) and (iii) remain untouched by the reasons-skeptical problem. Absent special revelation and obvious miracles, we have no reason to believe that God is intervening on our behalf, as Davison himself argues. Accordingly, we have no reason to believe that God is meddling in our affairs. The fact that we have no epistemic access to God's reasons does not entail or even suggest that God is meddling in our affairs. So the reasons-skeptical problem does not undermine benefit (ii). Benefit (iii) is completely independent of our beliefs, since God can refrain from meddling whether we think God meddles or not. So benefit (iii) is also untouched by the reasons-skeptical problem. So even if the reasons-skeptical problem undermines benefit (i), it does not undermine benefits (ii) and (iii). And arguably, benefits (ii) and (iii) are what we are really concerned about when it comes to divine meddling. If I have no reason to think that God is meddling in my affairs, and if God is in fact not meddling in my affairs, then I have no basis for resentment despite the significant power imbalance between myself and God.

Return now to the analogy with the rich and mysterious benefactor. Suppose you made it a habit of writing to your benefactor almost daily to inform her of your needs great and small. Sometimes these needs are met and sometimes they are not. If you have reason to believe that your benefactor is responsible for some of your needs being met, you might 
naturally begin to have a sense of gratitude toward your benefactor. You will not know for what it is appropriate to thank your benefactor, but it would be appropriate to have a general sense of gratitude. This is because you recognize that some and perhaps many of the good things you enjoy are due to your benefactor. Knowing that your benefactor sometimes acts on your behalf is therefore sufficient to recognize that some of your goods come from your benefactor. You depend on your benefactor for these goods, you have a sense of gratitude, and you recognize that you could not have had all the goods you enjoy without her help. Of course your sense of dependence and gratitude would be sharpened if you knew precisely for which goods your benefactor was responsible. But the fact remains that if you suspect that your benefactor answers some requests, then you should feel gratitude toward her, even if you do not know precisely for what goods you feel gratitude.

I conclude that the so-called reasons-skeptical problem is no problem at all. In order to reap the alleged benefits of petitionary prayer, it is not necessary to know exactly which prayers God answers; it is sufficient to have reason to believe that God answers some prayers for goods that are contingent on those prayers. Whether religious believers are justified in believing the latter claim, however, is another question. ${ }^{20}$

University of Groningen

\section{References}

Aquinas, Thomas. 1882. Opera omnia. Edited by the Leonine Commission (Comissio leonina).

Basinger, David. 1995. "Petitionary Prayer: A Response to Murray and Meyers." Religious Studies 31: 475-484. http://www.jstor.org/stable/20019775.

Basinger, David. 2004. "God Does Not Respond to Petitionary Prayer." In Contemporary Debates in Philosophy of Religion, edited by Michael Peterson and Raymond VanArragon (Blackwell), 255-264.

Choi, Isaac. 2016. "Is Petitionary Prayer Superfluous?" In Oxford Studies in Philosophy of Religion, edited by Jonathan Kvanvig (Oxford), 32-62.

https://doi.org/10.1093/acprof:oso/9780198757702.003.0002

Davison, Scott. 2011. "Petitionary Prayer." In The Oxford Handbook of Philosophical Theology, edited by Thomas Flint and Michael Rea (Oxford), 286-305.

https://doi.org/10.1093/oxfordhb/9780199596539.013.0014

\footnotetext{
${ }^{20}$ This paper was inspired by a fall 2016 course on philosophy of religion at the University of Toronto. Thanks to my excellent students for much stimulating discussion on this and other topics. The main idea of the paper was born from discussion of the topic with my wife, Megan Embry. Thanks to members of the University of Toronto philosophy of religion reading group, as well as to Klaas Kraay, Bryan Reece, Mark Murphy, and an anonymous referee, for valuable suggestions.
} 
Davison, Scott. 2017. Petitionary Prayer: A Philosophical Investigation (Oxford). https://doi.org/10.1093/acprof:oso/9780198757740.001.0001

Franks, W. Paul. 2009. "Why a Believer Could Believe That God Answers Prayers." Sophia 48: 319-324. https://doi.org/10.1007/s11841-009-0117-4

Hoffman, Joshua. 1985. “On Petitionary Prayer." Faith and Philosophy 2: 21-29. https://doi.org/10.5840/faithphil1985218

Howard-Snyder, Daniel, and Frances Howard-Snyder. 2010. "The Puzzle of Petitionary Prayer." European Journal for Philosophy of Religion 2: 43-68. https://doi.org/10.24204/ejpr.v2i2.367

Murray, Michael J. 2004. "God Responds to Petitionary Prayer." In Contemporary Debates in Philosophy of Religion, edited by Raymond VanArragon and Michael Peterson (Blackwell), 242-255.

Murray, Michael J., and Kurt Meyers. 1994. "Ask and It Shall be Given to You." Religious Studies 30: 311-330. https://doi.org/10.1017/S0034412500022927

Smith, Nicholas. 2013. "Philosophical Reflection on Petitionary Prayer." Philosophy Compass 8: 309-317. https://doi.org/10.1111/phc3.12010*

Smith, Nicholas, and Andrew Yip. 2010. "Partnership with God: A Partial Solution to the Problem of Petitionary Prayer." Religious Studies 46: 395-410. doi:10.1017/S0034412509990412

Stump, Eleonore. 1979. "Petitionary Prayer." American Philosophical Quarterly 16: 81-91. http://www.jstor.org/stable/20009745.

Stump, Eleonore. 1985. "Hoffman on Petitionary Prayer." Faith and Philosophy 2: 30-37. https://doi.org/10.5840/faithphil1985214

Veber, Michael. 2007. “Why Even a Believer Should Not Believe That God Answers Prayers." Sophia 46: 177-187. https://doi.org/10.1007/s11841-007-0021-8 